\title{
Smoking and smoking cessation in Latin America: a review of the current situation and available treatments
}

\author{
Fernando Müller' \\ Luis Wehbe ${ }^{2}$ \\ 'Universidad Nacional de Buenos \\ Aires and Proyecto Médico \\ Especialista en Dejar de Fumar, \\ Buenos Aires, Argentina; ${ }^{2}$ Ave Pulmo \\ Smoking Cessation Institute, Mar del \\ Plata, Argentina
}

\begin{abstract}
Tobacco smoking is a growing problem throughout Latin American countries, especially in underdeveloped countries where poverty and lack of education about the dangers of smoking may make people more susceptible to becoming smokers. Moreover, the economies of many Latin American countries have become dependent on the production of tobacco. Furthermore, because of the associated promotion of tobacco, smoking has integrated into many Latin American cultures. Nevertheless, the harmful health effects of tobacco use are well documented, including greatly increased risks of developing chronic obstructive pulmonary disease, cardiovascular disease, and many forms of cancer. The medical costs associated with treating these diseases far outweigh the economic benefits of producing and selling this deadly crop. To control the tobacco pandemic in Latin American countries, nicotine addiction must be recognized and treated as a disease. Governments, both national and local, need to be more involved in enacting anti-smoking policies such as higher tobacco taxation, control of illegal tobacco smuggling, and reimbursement of medical smoking cessation interventions. The training of health professions in the area of nicotine addiction must also be improved, so that they may better assist smokers in their quit attempts and advise patients on, and prescribe, effective smoking cessation pharmacotherapies.
\end{abstract}

Keywords: smoking, smoking cessation, tobacco, Latin America

\section{Introduction}

In only 6 centuries, the production and consumption of tobacco has been extended from the Americas to the rest of the world without respecting borders, cultures, or beliefs. During this period, tobacco consumption integrated naturally into different societies, such that about $80 \%$ of certain sectors of these populations have at least tried smoking (Zabert and Verra 2004; Müller and Zabert 2005).

Tobacco consumption is one of the greater pandemics of all time. Active smoking puts a patient at greater risk for developing chronic obstructive pulmonary disease (COPD) than any other single risk factor (USDH 1984, 1986, 1990). Of all the cases of COPD worldwide, $81.5 \%-90.0 \%$ can be attributed to a history of smoking (USDH $1984,1986,1990)$. COPD is often accompanied by other smoking-related comorbidities such as cancer, cardiovascular disease (CVD), and stroke (USDH 1990; Mackay et al 2006). Other chronic diseases such as osteoporosis are also prevalent in patients with COPD (Biskobing 2002). In addition, COPD has been linked to increased relative risk of hospitalization for and mortality from CVD (Huiart et al 2005; Sidney et al 2005), especially in patients under 65 years of age (Sidney et al 2005). Between COPD and other smoking-related diseases (eg, cancer and cardiovascular disease), smoking will eventually kill half of the current 1.25 billion smokers in the world (WHO 2002). Currently, smoking causes 5 million deaths annually (www.paho.org)
Correspondence: Fernando Müller Proyecto MEDEF, Pola II89, Capital Federal (1440), Argentina

Tel +54 I | 949483777

Fax +54 || 46357236

Email fwladimiro@speedy.com.ar 
and these death tolls are predicted to reach 1 billion people in the next century (Mackay et al 2006). These numbers will not be equally distributed throughout the entire world. Developed countries will experience 50\% increases in tobacco-related deaths, whereas underdeveloped countries will see smoking-related deaths increase by $700 \%$ (Crofton 1990; Mackay et al 2006). By 2030, tobacco consumption will kill up to 10 million people every year (Organización Mundial de la Salud 2000), and $70 \%$ of those deaths will occur in developing countries (Organización Mundial de la Salud 1999). Poverty and lack of education (Medina and Kaempffer 1991; Harwood et al 2007), and promotion of smoking in women (Jacobson et al 1989) and adolescents (Granero and Sanchez 2006) are key factors contributing to the exponential growth of the tobacco pandemic.

When faced with these issues, a few questions prevail. What makes tobacco consumption a universal phenomenon without geographic, idiomatic, or cultural limits? How, in only a few centuries, did tobacco consumption spread throughout the entire world from Latin America? Why does this pandemic continue to remain ignored, diminished, and disqualified, in spite of considerable evidence from more than a half century of research about the harmful effects of tobacco?

\section{Tobacco production}

The 2nd edtion of The Tobacco Atlas lists 20 Latin American countries that seed and cultivate tobacco (Table 1) (Mackay et al 2006). Currently, 5 out of the 25 largest tobacco producers in the world are countries of this region (Brazil, Argentina, Cuba, Dominican Republic, and Colombia) (Valdés-Salgado et al 2002). Brazil stands out as the second largest worldwide producer of tobacco, generating 928,300 tonnes annually, and as the top tobacco exporter (US\$1,052 million during 2003) (Mackay et al 2006). At the time of the data used in the 2 nd edition of The Tobacco Atlas, Argentina was the eighth largest worldwide producer $(118,000$ tonnes/year) (Mackay et al 2006). Now with a production of 161,000 tonnes/year (2006), however, it would occupy fifth place among the countries listed in The Tobacco Atlas. Overall in Latin America, tobacco production between 1995 and 2000 grew 29.5\%. During the same period, the amount of land used to cultivate tobacco increased by $10.3 \%$ and the yields per hectare improved by $17.3 \%$ (Valdés-Salgado et al 2002).

These data underscore the economic impact of tobacco production in Latin America, which presents a challenge for the next generations who will have to promote other strategies to break free from the economic dependence on tobacco (eg, substitution of plantations).

\section{Tobacco pricing}

Local economies determine how individual countries and tobacco producers price cigarettes. This is why, for example, Venezuela and Paraguay have the lowest worldwide prices of premium cigarettes like Marlboro (less than US\$1 for a pack of 20) (Mackay et al 2006). In Argentina, Brazil, Peru, Ecuador, Colombia, Mexico, Costa Rica, Panama, and Guatemala, prices oscillate between US\$1 and US\$1.99. In Chile, and Uruguay the cost varies from US\$2 to US\$2.9 (Mackay et al 2006). In addition, alternative brands of cigarettes may sell at much lower prices, such as in Argentina, where the prices of these cheap brands do not surpass US70 cents.

These low prices, in conjunction with underdeveloped conditions of much of Latin America, foster more tobacco consumption and constantly increase the total number of smokers, especially among adolescents and women (Mackay et al 2006). Furthermore, tobacco production is not associated with a higher index of wellbeing. The major tobaccoproducing provinces in Argentina, for example, show the smallest index of human development, the biggest percentage of insufficient basic needs, the highest illiteracy rate of the country, and the shortest life expectancy (Ministerio de salud-OPS 2006). The losses generated by smoking-related

Table I Tobacco cultivation in Latin America

\begin{tabular}{lll}
\hline Country & Hectares & Tonnes \\
\hline Argentina & 66,000 & 118,000 \\
Bolivia & 1,060 & 100 \\
Brazil & 469,678 & 928,300 \\
Chile & 2,970 & 9,300 \\
Colombia & 13,000 & 28,000 \\
Costa Rica & 117 & 200 \\
Cuba & 33,942 & 34,500 \\
Ecuador & 4,300 & 8,000 \\
El Salvador & 6000 & 1,100 \\
Guatemala & 9,232 & 20,500 \\
Haiti & 450 & 500 \\
Honduras & 1,170 & 5,200 \\
México & $11,46 \mathrm{I}$ & 21,900 \\
Nicaragua & 1,395 & 2,200 \\
Panama & 1,250 & 2,300 \\
Paraguay & 8,268 & 16,500 \\
Peru & 1,050 & 12,200 \\
Dominican Republic & 14,000 & 18,000 \\
Uruguay & 900 & 3,000 \\
Venezuela & 3,246 & 6,100 \\
Total & $\mathbf{6 4 4 , 0 8 9}$ & $1,235,900$ \\
\hline
\end{tabular}

644,089 hectares in Latin America are destined to seedtime, reaching a production of I,235,900 tonnes per year. Data derived from the 2006 Tobacco Atlas (Mackay et al 2006). 
diseases widely surpass the economic gains that the industry produces.

As of 2003, Argentina spends US\$1.4 million annually on the treatment of tobacco-related pathologies (Bruni Informe final 2004). This represents $15.5 \%$ of the total health care costs and these costs were not compensated by revenues from tobacco taxes (ie, US\$806 million in 2003) (Ministerio de Salud y Ambiente de la Nación 2005a). In Colombia, the losses from tobacco-related premature mortality and disease-related disability are 4 times greater than the income generated by tobacco in the economy of the country (Perez and Wiesner 2004).

One strategy to wean countries of their economic dependence on tobacco production would be to enact policies that raise the price of cigarettes. Not only would this increase the amount of taxes collected for each pack sold, but it may also reduce the prevalence of smoking (World Bank 1999). A $10 \%$ rise in the price of a pack of cigarettes, in high income countries, has been linked to a potential $4 \%$ decrease in smoking and in low to middle income countries; this benefit doubles to an $8 \%$ drop in smoking levels (World Bank 1999). Moreover, the effects of such a price increase is even more pronounced in adolescent smokers, with a $10 \%$ price increase yielding an estimated $14 \%-15 \%$ fall in smoking (Ding 2003, 2005). However, for price increase to be an effective measure, illegal tobacco smuggling would need to be controlled.

\section{Tobacco smuggling}

In Latin America, tobacco smuggling is a serious problem (Joossens and Raw 1998). A considerable circuit of illegal trade exists from Aruba (Dutch Antilles) to many Caribbean ports and Colombia (Anon 1989). Also since 2002, the illegal pathway from Paraguay to Argentina has grown considerably and today comprises $20 \%$ of the whole tobacco market (Misdorp 1990). Although Paraguay exports 2 billion cigarettes legally each year, its actual production is near 40 billion cigarettes. Since the country consumes 3 billion cigarettes a year, the final destinations of 35 billion cigarettes is unknown (Misdorp 1990). Although in 2006, Uruguay Customs seized 24 million illegal cigarettes worth US\$1 million, most of those cigarettes had come from Argentina and Paraguay (Presidencia de la República Oriental del Uruguay. 2007). Of course, not all the illegal cigarettes in Uruguay come from other countries; in fact, $80 \%$ of the cigarettes produced in Uruguay for export return to the country to be sold illegally (Presidencia de la República Oriental del Uruguay 2007). Other Latin American countries also are exposed to illegal smuggled cigarettes. Data from the Finances Secretary of Brazil, for example, indicate that falsification, illegal manufacturing, and smuggled products represented $30 \%$ of the total number of consumed cigarettes in 2005 (Fish-Menezes 2006). Also, 14\% of the cigarettes sold in Colombia in 2004 were counterfeit or smuggled (Anon 2005a). Stronger measures throughout Latin America must be implemented to bring a halt to this illegal cigarette trade, not only to prevent the economic losses due to uncollected taxes, but also to prevent its people from being exposed to cheap, unregulated cigarettes that further encourage smoking.

\section{Prevalence of tobacco consumption}

Data linked to the incidence of tobacco consumption in the region are few, and frequently controversial. According to the 2 nd ed of The Tobacco Atlas, the annual per person cigarette consumption in Latin American countries ranges between 500 and 1500 cigarettes per year (Mackay et al 2006), with the exception of Ecuador, Peru, Bolivia, and Paraguay, where the annual per person cigarette consumption is less than 500 cigarettes per year (Shafey et al 2003; ERC Statistics International 2004; US Department of Agriculture, Foreign Agricultural Service 2004; Mackay et al 2006).

Between $8 \%$ and $10 \%$ of the smokers of the world (ie, more than 120 million) live in Latin America (Mackay et al 2006), and thus, the smoking rates in Latin America are high (Table 2). Half of these smokers will die prematurely of a tobacco-dependent disease (WHO 2002).

\section{Tobacco use among adolescents}

Latin American data compiled from the Pan American Health Organization (PAHO) and the WHO show that $13.16 \%$ of young people between 15 and 18 years old are smokers (Organización Panamericana de la Salud 2005). The following countries have the highest youth smoking rates of the region: Chile (39.2\%), Colombia (33.4\%), Mexico (27.1\%), Argentina (25.8\%), and Uruguay (22.9\%). At the other extreme, Cuba (8.8\%), Dominican Republic (5.8\%), and Venezuela (8.4\%) possess the lowest youth smoking rates of the region (Table 2) (Warren et al 2008). Although there are significant variations between countryside (lower smoking prevalences) and urban zones (higher smoking prevalences), the rates vary between $20 \%$ and over $70 \%$, showing that use of tobacco is a common behavior among young Latin American people (Department of Health and Human Services, Centers for Disease Control and Prevention 2007). The addictive power of nicotine, the genetic predisposition of each "experimenter", and other personal (ie, social and 
Table 2 Prevalence of smoking in Latin America

\begin{tabular}{|c|c|c|c|c|}
\hline Country & Population $^{\dagger}$ & Male (\%) & Female (\%) & Total (\%) \\
\hline Argentina $^{a}$ & $36,772,000$ & 28.9 & 22.6 & 25.8 \\
\hline Bolivia $^{a}$ & $8,814,000$ & 31.0 & 28.6 & 29.9 \\
\hline Brazil $^{a}$ & $179,596,000$ & 21.4 & 12.7 & 16.9 \\
\hline Chile $^{a}$ & $15,774,000$ & 39.0 & 34.9 & 37.0 \\
\hline Colombia ${ }^{\mathrm{b}}$ & $44,584,000$ & 26.8 & 11.3 & 18.9 \\
\hline Costa Rica ${ }^{a}$ & $4,005,000$ & 2.5 & 3.5 & 3.0 \\
\hline Cuba $^{a}$ & $11,326,000$ & 43.1 & 26.5 & 34.8 \\
\hline Dominican Republic ${ }^{a}$ & $8,739,000$ & 15.3 & II.I & 13.2 \\
\hline Ecuador $^{\mathrm{a}}$ & $13,008,000$ & 7.9 & 1.9 & 4.8 \\
\hline El Salvador ${ }^{c}$ & $6,533,000$ & 42.1 & 14.8 & $N / A^{f}$ \\
\hline Guatemala $^{a}$ & $12,500,000$ & 7.7 & 0.9 & 4.1 \\
\hline Haiti $^{d}$ & $8,440,000$ & 10.7 & 8.6 & 9.5 \\
\hline Honduras ${ }^{\mathrm{b}}$ & $6,969,000$ & 36.0 & 11.0 & 24.0 \\
\hline Mexico $^{\mathrm{a}}$ & $102,291,000$ & 12.5 & 4.5 & 8.3 \\
\hline Nicaragua $^{e}$ & $5,480,000$ & $32.9^{f}$ & 7.8 & $21.0^{f}$ \\
\hline Panama ${ }^{b}$ & $2,984,000$ & 19.7 & 6.1 & 12.9 \\
\hline Paraguay ${ }^{\mathrm{a}}$ & $5,643,000$ & 23.6 & 7.4 & 15.5 \\
\hline Peru $^{\mathrm{b}}$ & $27,148,000$ & 52.5 & 17.8 & 33.8 \\
\hline Uruguay $^{\mathrm{a}}$ & $3,380,000$ & 35.0 & 25.1 & 29.8 \\
\hline Venezuela ${ }^{a}$ & $25,674,000$ & 26.7 & 23.3 & 25.0 \\
\hline
\end{tabular}

Data were collected from:

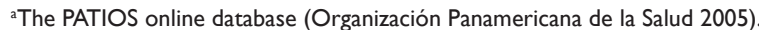

'2nd edition of The Tobacco Atlas of the American Cancer Society (Mackay et al 2006). 'Comisión Salvadoreña Antidrogas (Antidrug Commission of El Salvador) (Pan American Health Organization).

dNarcotics Awareness and Education Project (Haití: Developments Associates, Inc. 1991). ${ }^{e}$ Central American Diabetes Initiative (Organización Panamericana de la Salud 2003). ${ }^{\mathrm{f}} \mathrm{N} / \mathrm{A}$, not available.

psychological) factors will influence how many of these young people become smokers in the long term.

\section{Tobacco use among females}

The incidence of tobacco consumption in adult women ( $\geq 15$ years) varies by Latin American region and usually the data differ according to the source researched. However, Latin America is a good example of the worldwide female trend of increasing tobacco addition (Table 2). A country that clearly exhibits this trend is Chile, with $34.9 \%$ of women being smokers in the 2005 survey (Organización Panamericana de la Salud 2005). The female smoking trends in Argentina (22.6\%-30.7\%), Bolivia (28.6\%), Cuba (26.5\%), Uruguay (25.1\%), and Venezuela (23.3\%) are also worrisome. The country with the smallest frequency of female adult smokers is Guatemala with a rate of $0.9 \%$ on the 2005 survey (Organización Panamericana de la Salud 2005).

The numbers of females who are smokers are even more disquieting when analyzing the population of young women (15-18 years old) (Table 2). Colombia is the country with highest prevalence, reaching $31.0 \%$, followed by Chile (27.5\%), Ecuador (27.2\%), Mexico (26.3\%), and Nicaragua (25.6\%). The lowest levels of tobacco consumption in this population are in Venezuela (6.0\%), the Dominican Republic (7.3\%), and Brazil (9.1\%) (Warren et al 2008).

These data foretell a dire impact that tobacco-related diseases will have on the health of Latin American women, if smoking is not mediated with strong prevention measures and treatments against tobacco addiction. This is, and will continue to be, a big challenge for Latin America.

\section{Strategies for change}

The world is beginning to witness a great sociocultural change linked to tobacco. Nicotine addiction is more extensive than ever in human history and its serious consequences are universally recognized. The tobacco pandemic has necessitated a movement without precedent, in which nations from around the world must dictate policies to control its use and the consequences from it.

The WHO has warned about the dangers of tobacco and has been working for several years towards the establishment of changing strategies (World Health Organization 2007b). To this end, and after intense negotiations, 168 nations signed the Framework Convention on Tobacco Control (FCTC), which is the first international health pact that establishes the basis of a synchronized and unified fight of all of these countries against tobacco consumption (WHO 2007a). The FCTC has the objective "to protect present and future generations from the devastating health, social, environmental and economic consequences of tobacco consumption and

Table 3 Prevalence of smoking adolescents in Latin America

\begin{tabular}{lllll}
\hline Country & Year & Boys (\%) & Girls (\%) & Total (\%) \\
\hline Argentina & 2003 & 21.9 & 17.2 & 25.8 \\
Bolivia & 2003 & 16.3 & 20.3 & 12.0 \\
Brazil & 2005 & 12.3 & 9.1 & 12.9 \\
Chile & 2003 & 33.9 & 27.5 & 39.2 \\
Colombia & 2001 & 32.2 & 31.0 & 33.4 \\
Costa Rica & 2002 & 16.4 & 15.7 & 16.8 \\
Cuba & 2004 & 10.0 & 11.2 & 8.8 \\
Dominican Republic & 2004 & 6.6 & 7.3 & 5.8 \\
Ecuador & 2001 & 20.5 & 27.2 & 12.6 \\
El Salvador & 2003 & 14.0 & 18.4 & 10.9 \\
Guatemala & 2002 & 14.3 & 17.3 & 11.2 \\
Haiti & 2005 & 17.6 & 17.2 & 17.7 \\
Honduras & 2003 & 14.2 & 14.4 & 14.1 \\
Mexico & 2005 & 27.1 & 26.3 & 27.1 \\
Nicaragua & 2003 & 21.2 & 25.6 & 17.4 \\
Panama & 2002 & 13.2 & 14.7 & 11.1 \\
Paraguay & 2003 & 19.1 & 19.2 & 18.5 \\
Peru & 2003 & 19.2 & 20.8 & 17.0 \\
Uruguay & 2007 & 20.2 & 16.4 & 22.9 \\
Venezuela & 1999 & 7.4 & 6.0 & 8.4 \\
\hline
\end{tabular}

Data were derived from The Global Youth Tobacco Survey (Warren et al 2008). 
exposure to tobacco smoke by providing a framework for tobacco control measures to be implemented by the Parties at the national, regional and international levels in order to reduce continually and substantially the prevalence of tobacco use and exposure to tobacco smoke" (Molinari 2006; WHO 2007a).

The FCTC took effect February 27, 2005, and since this date, it has been ratified by 148 countries, including almost all the Latin American countries, with the exception of Argentina. In Argentina, the FCTC continues to be disputed by the Executive Power, which favors the FCTC, and the Legislative Power, where the representatives of the tobacco provinces refuse to accept the policies to the control tobacco. While each nation supporting the FCTC passes legislation to combat tobacco consumption, humanity as a whole must become aware of the magnitude of the problem. In Latin America, clinicians should make a serious effort to discourage smoking through patient education.

\section{Role of health care professionals}

One of the difficulties in controlling this epidemic is the lack of knowledge and training by doctors in treating tobacco addiction (Noble et al 1996; Zabert et al 1999; Minervini et al 1998, 2006; Ferrero et al 2004). Each member of the health team has a fundamental role in the treatment. Nurses, social workers, administrators, directors, primary care physicians, and specialist doctors must know that tobacco consumption is a disease. All of them should promote an open atmosphere of a health treatment to compel people to stop smoking by advising and assisting in the treatment process with a level of intervention appropriate for each particular case (Ministerio de Salud y Ambiente de la Nación 2005b).

When reviewing information about tobacco addiction that medical students from 18 Latin America countries receive, the conclusion was that only 6 countries offer tobacco education, 2 offer partial education, and 10 do not offer tobacco education at all (Table 4) (Organización Panamericana de la Salud 2005). In Argentina, for example, less than $30 \%$ of surveyed doctors acknowledged having received information on the subject (Rondelli et al 1999; Zabert et al 2002; Zabert and Verra 2004; Anon 2005b; Müller and Zabert 2005). Thus, the introduction of systematic education in tobacco consumption at medical schools needs to be implemented to contribute to the cultural change of health professionals.

Doctors must position themselves to be leaders in the fight against tobacco. They must get involved and fulfill their functions properly within their sphere of responsibilities. This is the model followed by countries that have experienced
Table 4 Tobacco education in medical schools

\begin{tabular}{llll}
\hline Country & Year & Tobacco education & $\begin{array}{l}\text { Date } \\
\text { received }\end{array}$ \\
\hline Argentina & 2002 & In some universities & $8 / 2002$ \\
Bolivia & 2002 & No & $8 / 2002$ \\
Colombia & 2002 & No & $9 / 2002$ \\
Ecuador & 2002 & No & $7 / 2002$ \\
Peru & 2002 & Yes & $7 / 2002$ \\
Venezuela & 2002 & No & $8 / 2002$ \\
Costa Rica & 2002 & Yes & $7 / 2002$ \\
El Salvador & 2006 & In some universities & $1 / 2006$ \\
Guatemala & 2002 & No & $7 / 2002$ \\
Honduras & 2002 & Yes & $12 / 2002$ \\
Nicaragua & 2002 & No & $8 / 2002$ \\
México & 2002 & Yes & $8 / 2002$ \\
Brazil & 2003 & No & $7 / 2003$ \\
Chile & 2002 & No & $7 / 2002$ \\
Paraguay & 2002 & Yes & $8 / 2002$ \\
Uruguay & 2002 & No & $8 / 2002$ \\
Dominican Republic & 2003 & No & $6 / 2003$ \\
\hline
\end{tabular}

Data were compiled form the Pan American Health Organization (Organización Panamericana de la Salud 2005).

success in controlling the tobacco epidemic (Rondelli et al 1999; Zabert et al 2002).

A lot of evidence indicates that health professionals who smoke are less active in the fight against tobacco consumption. They may have less confidence in their own advice; they may not believe in preventive intervention or in smoking cessation; and they may even lack trust in the treatments against nicotine (Rondelli et al 1999; Anon 2005b; Müller and Zabert 2005). Another issue is that the frequency of tobacco consumption among Latin American health professionals is similar to the levels of the general population; only in Brazil and El Salvador are significant differences observed, with indices up to 7\% (Mirra and Rosemberg 1997b; Sánchez and Lisanti 2003; Bello et al 2004; Monreal et al 2004; Anon 2005b; Müller and Zabert 2005; Mackay et al 2006; Zabert 2006).

Initiating policies to control tobacco consumption - in conjunction with the availability of successful medical alternative treatments for nicotine addiction - will increase the demand for smoking cessation programs. For these reasons, education and training of health teams in general, and of doctors especially, is indispensable. These health professionals can, in turn, assist smokers using therapeutic resources with proven ability, without fear of discrediting themselves. Furthermore, smoking cessation clinics of trained health professionals could be established where doctors could refer smokers for additional support and treatment.

In this context, the tobacco cessation guidelines adapted to each country, and in particular to the Latin America 
regions, are indispensable instruments to regulate treatments and to influence health professionals to be an active part of the tobacco cessation process. The guidelines must be based on the maximum evidence available and be agreed upon by a group of local leaders following a formal and rigorous consensus on methodology. A good example is the Argentinean treatment guidelines for tobacco addiction (Ministerio de Salud y Ambiente de la Nación 2005), for which planning and development were based on the NICE recommendations (National Institute of Clinical Excellence) (NICE 2007), and on the recommendations of AGREE (Appraisal of the Guidelines Research and Evaluation) (The Agree Collaboration 2001). Their main objectives are to increase the percentage of smokers who stop smoking, ensure that all health workers have the basic tools to facilitate the process of recovery from tobacco dependency, offer basic recommendations based upon the best evidence of efficacy and cost effectiveness of treatments to stop smoking, and adapt the national evidence to the local level in order to increase the feasibility and applicability of the recommendations.

Brazil, Costa Rica, Mexico, Panama, and Uruguay also have national guidelines, and are participating in a project to expand Latin American guidelines with the consensus of all the nations that comprise the region.

\section{Available pharmacological treatments}

Nicotine replacement therapies (NRT) may double the odds of successful abstinence from smoking compared to placebo (continuous abstinence from 6-12 months, pooled studies $\mathrm{N}=39,503$; odds ratio $[\mathrm{OR}]=1.77 ; 95 \%$ confidence interval [CI]: 1.66-1.88) (Silagy et al 2004). NRT in the form of gums and patches are available over the counter in almost all Latin American countries. In addition, Mexico has a nicotine oral inhalant (Sansores et al 2002). Only in some countries - such as Chile, Peru, and Venezuela - is a medical prescription necessary to buy NRTs (Organización Panamericana de la Salud 2005). Recently, the nasal spray became available in Argentina, but only under medical prescription. The most commonly observed adverse events (AEs) associated with NRTs includes pain in the jaw; gastrointestinal problems, hiccoughs, or orodental damage (gum); local skin irritation (patch); irritation or burning of the mouth or throat and coughing (inhaler); irritated or runny nose (nasal spray) (Silagy et al 2004).

A $2 \mathrm{mg}$ box of NRT gum (ie, a 3-day supply) costs between US\$10 and US\$16 in Colombia, Brazil, Uruguay, and Argentina (www.kairosweb.com). This price represents between $5 \%$ and $12 \%$ of the minimum salary. A box of
NRT gum costs the same as 9 packs (of 20 cigarettes) of the cheapest brand in Argentina, 10 packs in Uruguay, 12 in Colombia, and 21 in Brazil (www.kairosweb.com). The gap between the price of smoking cessation medication and cigarette packs is bigger in Latin America than in Western Europe, where medicines are proportionally more accessible and cigarettes are significantly more expensive. The recommended dosing schedules vary by the type of NRT and needs of the smokers, but can range from 12 weeks to 6 months or more (Pfizer, Inc 2005a, b; GlaxoSmithKline 2007a).

The medication bupropion is available in practically all the countries of the region and always requires a medical prescription (Organización Panamericana de la Salud 2005). Bupropion approximately doubles the odds of successful smoking cessation over placebo at 6 months or greater (pooled studies $\mathrm{N}=6433$; OR $=2.06$; 95\% CI: $1.77-2.40$ ) (Hughes et al 2004). The most commonly observed AEs include insomnia, dry mouth, headache, and jitteriness (Hughes et al 2004). As an antidepressant drug, bupropion is partially financed by many Latin American public health systems or private medical systems and its cost is usually lower than NRT. For example, a package of 30 tablets (ie, a 15-day supply) costs US\$13 in Uruguay and US\$18 in Argentina (www.kairosweb.com). The recommended dosing regimen is $150 \mathrm{mg}$ twice daily for 7-12 weeks (GlaxoSmithKline 2007b).

The medication varenicline became available beginning March/April of 2007 in Uruguay, Mexico, Chile, Brazil, and Argentina. Varenicline is the first non-nicotine pharmacotherapy developed for smoking cessation and may triple the odds of smoking cessation versus placebo (at 1 year, pooled studies $\mathrm{N}=1082$; OR $=3.22$; 95\% CI: 2.43-4.27) (Cahill et al 2007). The most commonly reported treatment-emergent AEs with varenicline are nausea, insomnia, headache, and abnormal dreams (Cahill et al 2007). The average cost of varenicline is US\$57 to US\$60 for a 2-week supply (www. kairosweb.com) and the recommended treatment period is 12 weeks (Pfizer, Inc 2007).

Presently, only Brazil and Uruguay have national laws to control tobacco consumption and offer free medication as part of a public health policy. In Argentina, some Municipal Hospitals in Buenos Aires provide free treatments in the clinics for smoking cessation. According to the PAHO (www.paho. org), almost all the Latin American countries have doctor's offices for smoking cessation, although the coverage is different between countries. Countries such as Brazil, Uruguay, Mexico, and Argentina have national tobacco control programs with specific goals that include health professionals 
with qualification for smoking cessation treatments. At the same time other countries still have not implemented these tools.

Drugs for the treatment of tobacco addiction are cost effective. It will be the responsibility of the health administrators, public and private, to fund tobacco cessation programs. These prevention measures will have a positive impact on the health of smokers.

\section{Conclusions}

Tobacco consumption is an addiction, accepted worldwide as a natural behavior, entrenched in established multicultural bases, propagated by advertising, and encouraged as a rapid wealth generator. The tobacco consumption problem is complex and involves social, cultural, economic, and public health aspects. Fighting the use of tobacco is a society's responsibility, which could be achieved through the combined efforts of societal institutions, governments, educators, and leaders.

To change the prognosis of the dangers of tobacco in the future, certain actions must be taken. These actions include: education, at all levels, about the real consequences of tobacco consumption; activation of public health policies to control tobacco consumption in order to protect minors and nonsmokers; commitment of the health professionals in general and doctors specifically; and participation of society as a whole. This is a pending and inescapable commitment for Latin America. Latin American territories have the most vulnerable conditions that expose them to the consequences of the tobacco epidemic. Latin America encompasses a group of countries still in development. In the majority of these countries, tobacco plantations are prevalent and tobacco products are commercialized (Valdés-Salgado et al 2002; Mackay et al 2006). Thus, the tobacco industry exercises powerful political influences for tobacco growth, such as eluding restrictions and accommodating tobacco production (Sebrié et al 2005; Zabert 2006). Smoking has integrated into the culture and customs of these countries, most of which are just now beginning tobacco control policies.

The harm caused by the tobacco consumption, the addictive characteristics of the disease, and the consequences of environmental tobacco smoke have spread greatly just in the last few years. Smoking tobacco is cheap and therefore within reach of almost all of the Latin American population. Health professionals also exhibit similar demographics of tobacco consumption to the population that they should help. They are generally poorly educated and trained on the topic, lacking knowledge about the prescribing and utility of available smoking cessation pharmacological treatments (Noble et al 1996; Mirra and Rosemberg 1997a; Minervini et al 1998; Rondelli et al 1999; Zabert et al 1999; Zabert et al 2002; Sánchez and Lisanti 2003; Bello et al 2004; Ferrero et al 2004; Monreal et al 2004; Zabert and Verra 2004; Anon 2005b; Organización Panamericana de la Salud 2005; Müller and Zabert 2005; Mackay et al 2006; Minervini et al 2006; Zabert 2006).

Considering these conditions, it can be speculated that tobacco consumption in Latin America will continue increasing in the future, especially affecting women and young people. However, the emergence of control policies, expansion of knowledge, and new therapeutic possibilities inspire hope. Therefore, all action towards tobacco control is anticipated and welcome. The commitment to the FCTC, the policies for tobacco control, and the creation of health reforms supporting and promoting tobacco cessation will be instruments of extraordinary value in this fight. For Latin America, it is urgent to educate health professionals to be part of the tobacco cessation effort, so that - with the arrival of new drugs and the application of better strategies adapted to their customs - more patients can stop smoking.

\section{Acknowledgments}

The authors would like to thank Beatriz Arreseygor, MD (Universidad de La Plata. MEDEF Project); Marcela Roseti MD (Universidad de Buenos Aires, MEDEF Project); Gabriela Senatore, MD (Universidad de Buenos Aires, MEDEF Project); Adriana Russo (Executive Secretary, MEDEF Project); and Jaquelina Herrera (Universidad de Buenos Aires). Drs Müller and Wehbe received unconditional honoraria from Pfizer Inc for writing this review. Editorial support for this review was provided by Ray Beck, Jr, PhD of Envision Pharma and was funded by Pfizer, Inc.

\section{References}

Anon. 1989. Latin American Issue. Tobacco International, 6.

Anon. 2005a. Country market insight, Colombia. Euromonitor Internacional, 6-7.

Anon. 2005b. Estudio FuMABA (Fumar en Médicos Asistenciales de hospitales de Buenos Aires) Informe preliminar. Presented at 33 Congreso Asociación Argentina de Medicina Respiratoria. Mendoza, Argentina.

Anon. 2006a. Anuario del tabaco 2005, SAGyP [online]. Accessed 25 February 2007. URL: http://www.sagpya.mecon.gov.ar/scripts/tab_prcia2.idc

The Agree Collaboration. 2001. AGREE Instrument Spanish version [online]. Accessed 8 July 2007. URL: http://www.agreecollaboration.org.

Bello S, Soto M, Michalland M, et al. 2004. Encuesta nacional de tabaquismo en funcionarios de salud. Rev Méd Chile, 134:223-32.

Biskobing DM. 2002. COPD and osteoporosis. Chest, 121:609-20.

Bruni JM. 2004. Ministerio de Salud y Ambiente de la Nación. Proyecto VIGIA. Informe final 2004. Costos Directos de la Atención Medica de las Enfermedades Atribuibles al Consumo de Tabaco en Argentina. 
Cahill K, Stead L, Lancaster T. 2007. Nicotine receptor partial agonists for smoking cessation. Cochrane Database Syst Rev, CD006103.

Crofton J. 1990. Tobacco and the third world. Thorax, 45:164-9.

Department of Health and Human Services, Centers for Disease Control and Prevention. 2007. Global Youth Tobacco Survey. Country Reports: Pan American Health Organization [online]. Accessed 23 March 2007. URL: www.cdc.gov/tobacco/global/GYTS/reports/ paho/reports.htm.

Ding A. 2005. Curbing adolescent smoking: a review of the effectiveness of various policies. Yale J Biol Med, 78:37-44.

Ding A. 2003. Youth are more sensitive to price changes in cigarettes than adults. Yale J Biol Med, 76:115-24.

Droguería Vida Bucaramanga de Colombia, Farmacia Soudriers de Uruguay, Farmacia Klein de Argentina [online]. Accessed 25 August 2007. URL: www.kairosweb.com

ERC Statistics International. 2004. The World Cigarette Market: The 2004 Survey. Suffolk, UK.

Ferrero F, Castaño C, Durán P, et al. 2004. Grupo de Estudio del Tabaquismo en la Residencia de Pediatría. Prevalencia del consumo de tabaco en médicos residentes de pediatría en Argentina. Rev Panam Salud Publica, 15:395-9.

Fish-Menezes M. 2006.The illegal market in Brazil. Presented at the first meeting of the WHO expert committee on the illicit tobacco trade. 2006. Geneva, Switzerland.

GlaxoSmithKline. 2007a. Smoking Cessation Resource Center [online]. Accessed 26 September 2007. URL: http://www.gsk-scrc.com/.

GlaxoSmithKline. 2007b. Zyban (bupropion hydrochloride) [US prescribing information]. Research Triangle Park, NC.

Granero R and Sanchez M. 2006. [Changes in tobacco use and related factors in Junior High School students, Lara State, Venezuela, 2000-2003]. Cad Saude Publica, 22:1893-9.

Harwood GA, Salsberry P, Ferketich AK, et al. 2007. Cigarette smoking, socioeconomic status, and psychosocial factors: examining a conceptual framework. Public Health Nurs, 24:361-71.

Hughes J, Stead L, Lancaster T. 2004. Antidepressants for smoking cessation. Cochrane Database Syst Rev, CD000031.

Huiart L, Ernst P, Suissa S. 2005. Cardiovascular morbidity and mortality in COPD. Chest, 128:2640-6.

Jacobson B, Amos A, Aghi M. 1989. World no tobacco day: a challenge for women's health. Lancet, 1:1193-4.

Joossens L, Raw M. 1998. Cigarette smuggling in Europe: who really benefits? Tob Control, 7:66-71.

Mackay J, Eriksen M, Shafey O. 2006. In Lacey C, King J, Mayne S (eds). The Tobacco Atlas. Atlanta, GA: American Cancer Society.

Medina E, Kaempffer AM. 1991. [Smoking and health in Chile]. Bol Oficina Sanit Panam, 111:112-21.

Minervini MC, Patiño C, Zabert G, et al. 1998. Smoking prevalence among Argentine physicians. AJRCC, 157:A504

Minervini MC, Zabert GE, Rondelli MPP, et al. 2006. Tobacco use among Argentine physicians: personal behavior and attitudes. Revista Argentina de Medicina Respiratoria, 6:100-105.

Ministerio de salud-OPS. 2006. Indicadores Básicos 2006. [online]. Accessed 17 March 2007. URL: www.msal.gov.ar.

Ministerio de Salud y Ambiente de la Nación. 2005a. Guía Nacional de Tratamiento de la adicción al tabaco [online]. Accessed 8 April 2007. URL: www.msal.gov.ar.

Ministerio de Salud y Ambiente de la Nación. 2005b. Primera Encuesta Nacional de Factores de Riesgo [online]. Accessed 21 April 2007. URL: www.msal.gov.ar.

Mirra AP, Rosemberg J. 1997a. Inquérito sobre prevalência do tabagismo na classe médica brasileira. Rev Assoc Med Bras, 43:209-16.

Mirra AP, Rosemberg J. 1997b. [Survey on prevalence of smoking among Brazilian physicians]. Rev Assoc Med Bras, 43:209-16.

Misdorp S. 1990. Paraguay Report. Tobacco International, 36.

Molinari M. 2006. Legislación de Control de Tabaco. In F Müller (ed) Cesación Tabáquica: Tiempo de Intervenir. Buenos Aires, Argentina: Polemos Editorial.
Monreal LA, Tezoquipa IH, Jasso R, et al. 2004. Prevalencia de tabaquismo de médicos y enfermeras en los Estados de Morelos y Guanajuato. Rev Inst Nal Enf Resp Méx, 17:261-5.

Müller F, Zabert G. Prevalencia de Tabaquismo en profesionales de la salud mental. Presented at 33 Congreso Asociación Argentina de Medicina Respiratoria. 2005. Mendoza, Argentina.

NICE. 2007. Guidelines developments methods. Information for national collaborating centres and Guidelines Developers [online]. Accessed 8 July 2007. URL: www.nice.org.uk.

Haití: Developments Associates, Inc. 1991. Narcotics Awareness and Education Project. (NAE). National study of drug prevalence and attitudes towards drug use in Haití.

Noble M, Pérez-Stable E, Casal E. 1996. El comportamiento médico en relación al tabaquismo. Boletín de la Acad Nac de Medicina, 74:413-25

Organización Mundial de la Salud. 1999. Informe Sobre la Salud en el Mundo [online]. Accessed URL: www.who.int/whr/1999/en/whr99_ dgmessage_es.pdf.

Organización Panamericana de la Salud. 2003. Encuesta de Diabetes e Hipertensión y sus factores de Riesgo. Central American Diabetes Initiative (CAMDI).

Organización Panamericana de la Salud. 2000. La epidemia de tabaquismo: Los gobiernos y los aspectos económicos del control del tabaco [online]. Accessed 13 March 2007. URL: www.paho.org/spanish/DBI/PC577/ PC577_prelim.pdf.

Organización Panamericana de la Salud. 2005. Sistema Panamericano de Información en Línea de Tabaco (PATIOS) [online]. Accessed 20 April 2007. URL: http://www.paho.org/tobacco/SpaPatiosHome.asp.

Pan American Health Organization [online]. Accessed 20 April 2007. URL: www.paho.org.

Pan American Health Organization. 2003. Comisión Salvadoreña Antidrogas. COSA. Information provided by WHO PAHO regional office.

Perez P, Wiesner C. 2004. Años perdidos de vida saludable por muerte prematura e incapacidad, asociados al consumo de cigarrillo en Colombia. Revista Colombiana de Cancerología, 8:21-27.

Pfizer, Inc. 2005a. Nicotrol Inhaler (nicotine inhalation system) [US prescribing information]. Morris Plains, NJ.

Pfizer, Inc. 2005b. Nicotrol NS (nicotine nasal spray) [US prescribing information]. Morris Plains, NJ.

Pfizer, Inc. 2007. Chantix (varenicline) [US prescribing information]. New York, NY.

Presidencia de la República Oriental del Uruguay. 2007. Edicíon Completa de la Investigación Detenidos Desaparecidos [online]. Accessed 22 August 2007. URL: www.presidencia.gub.uy/_Web/noticias/2007/06/200706509.htm

Rondelli P, Zabert G, Minervini MC, et al. 1999. Physician's knowledge and attitude towards tobacco. AJRCC, 159:A487.

Sánchez P, Lisanti N. 2003. Prevalencia de tabaquismo y actitud hacia ese hábito entre médicos del Azuay, Ecuador. Rev Panam Salud Publica, 14:25-30.

Sansores RH, Ramírez-Venegas A, Espinosa-Martínez M, et al. 2002. Tratamientos para dejar de fumar, disponibles en México. Salud Publica Mex, 44:S116-24.

Sebrié EM, Barnoya J, Pérez-Stable EJ, et al. 2005. Tobacco industry successfully prevented tobacco control legislation in Argentina. Tob Control, 14:e2.

SEDRONAR. 1999. Encuesta nacional de sustancias psicoactivas [online]. Accessed 14 May 2007. URL: www.sedronar.gov.ar.

Shafey O, Dolwick S, Guindon GE. 2003. (eds) Tobacco Control Country Profiles 2003. Atlanta, GA: American Cancer Society.

Sidney S, Sorel M, Quesenberry CP Jr, et al. 2005. COPD and incident cardiovascular disease hospitalizations and mortality: Kaiser Permanente Medical Care Program. Chest, 128:2068-75.

Silagy C, Lancaster T, Stead L, et al. 2004. Nicotine replacement therapy for smoking cessation. Cochrane Database Syst Rev, CD000146.

US Department of Agriculture, Foreign Agricultural Service. 2004c. Tobacco: World Markets and Trade [online]. Accessed 11 April 2007. URL: http//www.fas.usda.gov/currwmt.html. 
[USDH]. 1984. US Department of Health and Human Services, Public Health Service, Centers for Disease Control, Center for Chronic Disease Prevention and Health Promotion, Office of Smoking and Health. The Health Consequences of Smoking: Chronic Obstructive Lung Disease. DHS Publication No. (CDC) 84-50205.

[USDH]. 1986. US Department of Health and Human Services, Public Health Service, Centers for Disease Control, Center for Chronic Disease Prevention and Health Promotion, Office of Smoking and Health. The Health Consequences of Involuntary Smoking. DHS Publication No. (CDC) 87-8398.

[USDH]. 1990. US Department of Health and Human Services, Public Health Service, Centers for Disease Control, Center for Chronic Disease Prevention and Health Promotion, Office of Smoking and Health. The Health Benefits of Smoking Cessation. DHS Publication No. (CDC) 90-8146.

Valdés-Salgado R, Hernández-Ávila M and Sepúlveda-Amor J. 2002. El consumo de tabaco en la Región Americana: elementos para un programa de acción. Salud Pública México, 44:S125-S135.

Warren WW, Jones NR, Peruga A, et al. Global Youth Tobacco Surveillance, 2000-2007. MMWR, 57:1-21.
World Bank. 1999. Curbing the Epidemic: Governments and the Economics of Tobacco Control: Washington, DC.

[WHO] World Health Organization. 2002. The World Health Report: Reducing Risks, Promoting Healthy Life, Geneva.

[WHO] World Health Organization. 2007a. WHO Framework Convention on Tobacco Control (WHO FCTC) [online]. Accessed 21 April 2007. URL: http://www.who.int/tobacco/framework/en/.

[WHO] World Health Organization. 2007b. [online]. Accessed 27 September 2007. URL: http://www.who.int/topics/tobacco/en/.

Zabert G. 2006. Chapter 7: Los médicos y el tabaco. In FW Müller (ed) Cesación Tabáquica: Tiempo de Intervenir. Buenos Aires, Argentina: Editorial Polemos. 127-38.

Zabert G, Cecchini M, Rucci C, et al. Prevalencia de fumar en estudiantes de medicina de la UNComahue. Presented at AAMR. 2002.

Zabert G, Rondelli P, Minervini MC, et al. 1999. Smoking behavior in Argentine physicians. AJRCC, 159:A486.

Zabert G, Verra F. FUMAr. (Fumar en universitarios de medicina de Argentina). Presented at 32 Congreso Asociación Argentina de Medicina Respiratoria IV Congreso Asociación Latino-Americana del Tórax. 2004. Buenos Aires, Argentina. 
